was not reliable enough for the diagnosis of sporadic cases of acute Sonne dysentery should be revised. Our confidence in the immunofluorescence technique described in this paper is such that it is our current practice to examine specimens from cases of acute diarrhoea immediately on arrival in the laboratory and to inform the doctor by telephone as soon as a positive result by fluorescence microscopy is obtained, emphasizing that such a report should be regarded as provisional and subject to confirmation by culture. With the fluorescent antibody technique in the manner here described, a provisional diagnosis can be made with reasonable confidence in cases of acute Sonne dysentery within one hour of the faecal specimen arriving in the laboratory.

The very much better agreement in this study between immunofluorescence and culture, as compared with that of Taylor et al. (1964), is probably related to the way in which the microscopical preparations were examined and evaluated, although changes in the technique of making the microscopical preparations, which were introduced mainly for reasons of convenience, could have contributed to the overall improvement. Searching for fluorescing organisms along the edges of smears may have reduced the number of false-negative results, and disregarding fluorescent particles other than those having the typical morphology of fluorescing $S h$. sonnei probably reduced the number of false-positive ones. There is little doubt that in the earlier study many of the false-positive results were caused by attaching significance to fluorescing particles not having the typical morphology of fluorescing Sh. sonnei, because at that time it was thought that morphologically atypical forms might well occur in faeces. Our experience has shown, however, that in microscopical preparations of faecal specimens from cases of acute Sonne dysentery fluorescing organisms of typical morphology are usually seen in large numbers.

\section{Summary}

A fluorescent antibody technique for the detection of $S h$. sonnei in specimens of faeces from cases of acute diarrhoea is described. It has been compared with a cultural method. The two procedures agreed in $95.6 \%$ of 388 specimens examined; $7(1.8 \%)$ of the results are regarded as "false positive" by the fluorescence technique and $10(2.6 \%)$ are regarded as "false negative." The technique enables a provisional report to be telephoned within one hour of a specimen arriving in the laboratory, and is regarded as a useful procedure for the rapid diagnosis of Sonne dysentery, provided it is combined with a cultural method.

We are grateful to Dr. R. C. J. James, Director of the Public Health Laboratory at Neasden Hospital; to Dr. K. Machacek, Director of the Public Health Laboratory at Coppetts Wood Hospital ; and to Dr. M. E. M. Thomas, Director of the Public Health Laboratory at Edmonton, for sending us fresh specimens of faeces and allowing us to use their results of culture. The antisera used for preparing the fluorescent conjugates were kindly supplied by Dr. C. M. P. Bradstreet, Director of the Standards Laboratory for Serological Reagents, Colindale.

\section{REFERENCE}

Taylor, C. E. D., Heimer, G. V., Lea, D. J., and Tomlinson, A. J. H. (1964). अ. clin. Path., 17, 225.

\title{
Congenital Rubella Infection of a Human Embryo
}

\author{
H. E. M. KAY,* M.D., M.R.C.P. ; MARGARET E. PEPPERCORN, M.B., B.CH. ; J. S. PORTERFIELD,† M.D., M.R.C.S. \\ K. MCCARTHY, $\ddagger$ M.D. ; C. H. TAYLOR-ROBINSON,§ M.B., B.S.
}

Brit. med. F., 1964, 2, 166-167

The association between maternal infection with rubella (German measles) and the subsequent birth of a deformed child was first noted by Gregg (1941) and has been amply confirmed by later reports. Little progress could be made on studying the mechanism whereby these congenital defects were produced until satisfactory means were found for cultivating the virus in the laboratory (Weller and Neva, 1962 ; Parkman et al., 1962 ; McCarthy et al., 1963).

During the spring and summer of 1962 a number of human embryos from pregnancies which were terminated after maternal exposure to rubella became available for study. Attempts were made to demonstrate the presence of virus in cultures prepared from this material. This paper describes the isolation of rubella virus from one of these embryos.

\section{Materials and Methods}

Embryo 13 was removed by hysterotomy performed $23 \frac{1}{2}$ weeks after the last menstrual period on a mother who gave

* Consultant Clinical Pathologist, Royal Marsden Hospital, London.

† Member of Scientific Staff, National Institute for Medical Research, Mill Hill, London.

‡ Senior Lecturer, Department of Bacteriology, University of Liverpool.

$\S$ Research Fellow, Department of Bacteriology, University of Liverpool. a history of an attack of rubella during the fifth week of pregnancy. Lung tissue was minced and trypsinized overnight at $4^{\circ} \mathrm{C}$., and cultures were set up in Gey's solution containing lactalbumin hydrolysate and newborn calf serum (Porterfield, 1962). Subcultivation of cells was carried out, using essentially the method of Hayflick and Moorhead (1961). Cells homogenized in medium were frozen at $-70^{\circ}$ C. for later examination.

\section{Results}

Homogenates of third-passage-level human embryonic lung cells were used to infect cultures of rabbit-kidney cells of the strain GL RK13. These produced a cytopathic effect visible by direct and phase contrast microscopy, which was reproduced by the third to the fifth day in seven serial cultivations in rabbit cells. Control cultures subcultured at the same time remained negative.

Neutralization tests were carried out, using serum from a rabbit immunized by five intravenous injections of GL RK13 grown rubella virus (strain "Judith") which had been isolated in Liverpool. The seventh GL RK13 pass of HEL $13 / 3$ virus was neutralized by this serum at a dilution of $1: 32$, and a similar dose of "Judith" virus was neutralized by 
serum diluted 1:64. Pre-immunization serum from this rabbit effected no neutralization at a dilution of $1: 4$. Fresh normal rabbit serum diluted $1: 3$ was used to potentiate the neutralization as discussed elsewhere (McCarthy et al., 1963).

\section{Discussion}

Selzer (1963) has reported the successful isolation of a strain of rubella virus from human embryonic tissues. In her case rubella infection during early pregnancy resulted in spontaneous delivery of a $20-\mathrm{mm}$. embryo ten days later. Virus was demonstrated in vervet-monkey-kidney cell cultures after these had been treated with a trypsinized suspension of human embryonic cells, but cultures set up with human embryonic material failed to grow.

In the present case virus appears to have persisted within the human embryo for some four and a half months after the mother's attack of rubella. Cultures of human embryonic lung cells grew well and showed no clear evidence of abnormality. Virus was demonstrated in homogenates of thirdpassage-level human embryonic lung cells, using a line of rabbit-kidney cells as an indicator system. The strain of virus is serologically related to another strain of rubella virus isolated in the United Kingdom, and its behaviour in rabbit- kidney cells resembles that of several other British strains and of the "Magaldi" strain isolated in New Haven by Dr. Dorothy Horstmann.

\section{Summary}

Cultures prepared from the lungs of a twenty-three-and-ahalf-week-old human embryo removed by hysterotomy from a mother who had been exposed to rubella during the fifth week of pregnancy have been found to be carrying rubella virus.

The GL RK13 strain of rabbit-kidney cells was supplied by Dr. A. J. Beale, Glaxo Research Ltd. Thanks are expressed to Mrs. Sylvia Stock for technical assistance.

\section{REFERENCES}

Gregg, N. M. (1941). Trans. ophthal. Soc. Aust., 3, 35. Hayflick, L., and Moorhead, P. S. (1961). Exp. Cell. Res., 25, 585. McCarthy, K., Taylor-Robinson, C. H., and Pillinger, S. E. (1963). Lancet, 2, 593.

Parkman, P. D., Buescher, E. L., and Artenstein, M. S. (1962). Proc. Soc. exp. Biol. (N.Y.), 111, 225.

Porterfield, S. (1962). Nature (Lond.), 194, 1044.

Pelzer, G. (1963). Lancet, 2, 336.

Weller, T. H., and Neva, F. A. (1962). Proc. Soc. exp. Biol. (N.Y.), 111, 215 .
Rabies has been kept out of England by physical control of the dog population. The last human case reported here was in 1956 (see B.M.F., 21 September 1963, p. 700). The patient, a man bitten by a dog in Pakistan two months earlier, had not sought preventive treatment. Before then, within the preceding ten years, there were two similar deaths of men in the armed Forces. From time to time, owing to the volume and speed of modern air travel, possible cases of infection with rabies are introduced into Great Britain. These cases may present a difficult problem in diagnosis, as the following case dramatically illustrates.

\section{CASe Report}

The patient, a Pakistani aged 22, came to England only two months before his illness. On 7 September 1963, about midnight, he was sent by his doctor to Dewsbury General Hospital. He had not been well for a few days and was attending his doctor for generalized aches and pains. As he could not speak English he was sent to the hospital on the chance that some of the doctors resident there understood his language and might be able to help him.

On admission he complained of pain all over his body, particularly in the right leg and lumbo-sacral region. His father said he had passed some blood in his urine four days previously. He was exceedingly restless, sweating profusely and rolling about intermittently in agony. At times he sat up in bed holding his penis.

The patient was a well-built healthy young man, clearly very apprehensive. Physical examination showed: pulse 80, regular, large in volume ; temperature $96^{\circ} \mathrm{F}$. $\left(35^{\circ} \mathrm{C}\right.$.) ; blood-pressure $180 /$ $80 \mathrm{~mm} . \mathrm{Hg}$; abdomen soft ; no tenderness in renal angles; reflexes normal ; optic fundi normal ; no evidence of meningeal irritation.
His legs showed no abnormality apart from a healed linear scar on the right ankle. A provisional diagnosis of renal colic was made and he was given an analgesic by injection. The night nurse reported that he had continued to be restless, had had a poor night, had taken drinks several times, and had passed $10 \mathrm{oz}$. (285 ml.) of turbid urine. He had also had several rigors.

Next morning, at 9 a.m., he developed pyrexia. His temperature was $100^{\circ} \mathrm{F}$. $\left(37^{\circ} \mathrm{C}\right.$.) and he was still sweating profusely. A urine examination showed a trace of albumin with no R.B.C. or pus cells. Culture revealed no growth. Investigations also showed: $\mathrm{Hb}$ $108 \%$; W.B.C. $12,000 /$ c.mm. (neutrophils $85 \%$, lymphocytes $10 \%$, monocytes $5 \%$ ) ; E.S.R. $7 \mathrm{~mm}$. in the first hour. No malaria parasites were seen in the blood films. Serum bilirubin was $0.7 \mathrm{mg}$. At midday he became violent and manic, shouting at the top of his voice and begging for help. He would not listen even to his father. As before, he was extremely apprehensive and sweated profusely. So violent were his movements that it was difficult to keep him in bed with the help of two porters.

A thorough re-examination revealed no new features. Pulse rate was 96 ; temperature $100^{\circ}$ F. $\left(37^{\circ}\right.$ C. $)$. As some form of encephalitis appeared to be present, a lumber puncture was performed under sedation with paraldehyde and "largactil" (chlorpromazine). The C.S.F. was clear and under normal pressure. It contained: protein 20 mg.; lymphocytes 40 ; R.B.C. 10 ; sugar $95 \mathrm{mg}$.; and chloride $780 \mathrm{mg}$. Wassermann reaction was doubtful and Price's precipitation reaction negative. The Lange test was normal. Later C.S.F. culture was reported to have no growth. At this stage electrolyte estimation showed: sodium 140, potassium 4.4, chloride 103, bicarbonate $33 \mathrm{mEq} / 1$., blood urea $62 \mathrm{mg}$.

By 4 p.m. the condition of the patient had deteriorated. $\mathrm{He}$ developed a tachycardia $(160 / \mathrm{min}$.) and his blood-pressure fell to $80 / 50 \mathrm{~mm}$. Hg. He was under sedation. At this time opisthotonos was noted. The possibility of viral encephalitis was strengthened by the C.S.F. report, but the muscle spasm also suggested tetanus. On being asked about any recent injury the father said that his son, while in Pakistan, had been bitten by a dog on the right leg three months previously. He did not know whether the dog was rabid. The patient continued to deteriorate and died in the evening from cardiorespiratory failure. 